Ethiopian Journal of Environmental Studies \& Management 9 (2): 121 - 136, 2016.

ISSN:1998-0507

doi:http://dx.doi.org/10.4314/ejesm.v9i2.1

Submitted: August 19, 2015

Accepted: February 15, 2016

\title{
A COMPARISON OF THE BOATING AND SWIMMING MICROBIAL WATER QUALITY OF CALABAR RIVER AND CROSS RIVER ESTUARY, NIGERIA
}

\author{
${ }^{*}$ SHOWELL, J.0.,1 EZE, E.B. ${ }^{2}$ AND AMA-ABASI, D.E. ${ }^{1}$ \\ ${ }^{1}$ Institute of Oceanography, University of Calabar, Calabar, Nigeria \\ ${ }^{2}$ Department of Geography, University of Calabar, Calabar, Nigeria
}

\begin{abstract}
Calabar River Estuary is often used by both locals and tourists for boating and swimming making it necessary to assess the microbial recreational water quality of this water body. Five sampling stations were established - 3 in Calabar River and 2 in the Estuary. Calabar River stations were inshore while the estuarine stations were outshore. Sampling was fortnightly and twice on sampling days to cover flood and ebb tides. Water samples were analyzed for total coliform, fecal coliform and intestinal Enterococci. The highest count of intestinal Enterococci (191cfu/100ml) was recorded in station 3 during flood tide in July. Station 2 had the lowest count $(17 \mathrm{cfu} / 100 \mathrm{ml})$ of intestinal Enterococci and this was in November during the dry season and during low tide. The $95^{\text {th }}$ percentile of the highest and lowest count of intestinal Enterococci was $190 / 100 \mathrm{ml}$ and $14 / 100 \mathrm{ml}$ respectively. The highest total coliform count (1900cfu/100ml) was recorded at station 3 in July during flood tide while the lowest (163cfu/100ml) was recorded also station2 during ebb tide in November. Almost the same scenario was observed for fecal coliform. The highest count (250cfu/100ml) was recorded at station 3 in July during flood tide while the lowest count (27cfu/100ml.) was recorded at station 2 in February during ebb tide. Statistical analysis using t- test indicated that there is no significant difference in microbial water quality between Calabar River and the Estuary. All the sampled stations met the WHO, and EC standards for safe recreational waters.
\end{abstract}

Key Words: Boating, Swimming, Water quality, Total coliform, Fecal coliform, Enterococci

\section{Introduction}

Rivers have always been the focus of human settlement and recreation. The banks of Calabar River and Estuary are not an exception. Residential, recreational, tourist and industrial developments and roads take place here. The catchment often supports a range of land uses such as housing, agriculture and forestry. All these activities can pollute waterways. Waste

*Corresponding Author: Showell, J.O.

Email: showelljack@yahoo.com discharges, accidental spills, urban and agricultural runoff, and groundwater flow carry a wide range of pollutants which impact water quality (UNEP, 2001).

According to Arnolds and Gibbons (1996), a recognized major source of microbial contamination to surface waters is storm water runoff. Storm water runoff contributes to a significant pollution load in coastal waters as well as in urbanized 
areas. Rain falling on impervious surfaces, including pavement, roofs, sidewalks, patios, bedrock outcrops and compact soil are washed off and carried along into the rainfall runoff and into surface waters. In Wisconsin, for example, the highest levels of Escherichia coli in runoff were detected in residential and commercial areas (Bannerman et al., 1993). The bacteria were also from roof, parking lot, driveway and sidewalk sources.

On the other hand, public health and especially the health of beach goers are severely threatened by the disposal of raw sewage to the storm water that flows out into the River. Children, elderly people, and those with relatively lower resistance to infection by bacteria and other microorganisms are especially at risk (City of Sao Paulo, 1998). Adelegen (2004) writing on the history of water resources in Nigeria and the way forward concluded that water pollution has continued to generate unpleasant implications for health and economic development in Nigeria and the third world in general. Also, Asuquo (1999) working on anthropogenic pollution of surface waters of Calabar river concluded that the river is heavily contaminated by hydrocarbons and said the protection of the quality of coastal waters must be reasonably ensured. Similarly, in a prospective study to investigate the microbial water quality of Doula lagoon, Cameroun, Akoachere et al. (2008) concluded that the pressure of potential bacterial agents in the lagoon may pose a serious threat to the health and well being of users of the water body and called for urgent intervention. The Calabar River flows through the city of Calabar and into the Estuary. In the city, although there are municipal waste dumping and gathering facilities, solid waste are often left overflowing from dumpsters and spilling on the streets and in the gutters where they decay and may be washed off by surface runoff into nearby waters during the rains. Located at the proximity of the water body are also subsistent farmlands, government and industrial establishments. This is why this study became necessary so as to evaluate which section of the water body is most impacted microbiologically by these anthropogenic activities. The city of Calabar is fast becoming an attractive tourist destination which brings up the need to have a picture of the quality of the coastal waters in terms of its usage for recreation.

\section{Study Area}

The Calabar River takes its rise from Oban Hills of the South-Eastern Nigeria and meanders South-North, covering an estimated area of $1669 \mathrm{~km}^{2}$ before discharging into the Cross River Estuary at Calabar (CRBDA, 1982). The River Estuary is located between latitude $4^{0} 54$ ' and $5^{0} 50^{\prime} \mathrm{N}$ and longitudes $8^{0}$ and $8^{0} 24^{\prime} \mathrm{E}$ (figs.1and 2). It ranges in depth from less than $1 \mathrm{~m}$ at the shores to about $10 \mathrm{~m}$ along dredged navigational channels. The climate of the Cross River Basin has been described by Eze and Effiong (2010). The area has a wet season which starts in April and ends in September. Average rainfall is 1,830 millimeters and average temperatures range from $24^{\circ} \mathrm{C}$ to $30^{\circ} \mathrm{C}$. Relative humidity is high ranging between $80 \%$ and $100 \%$. The dominant vegetation in the study area is mangrove which gives way to the rain forest further north of Calabar. Human settlement with business and agricultural activities are concentrated on the east coast of the River leading to marked reduction in forest cover while the west is thickly forested with little human influence. 
Sampling points were selected taking into consideration the anthropogenic activities going on at these sampling stations and also because this area is where the boating and swimming activities take place. Tourists often take boat rides in the River through Marina resort and into the Estuary thereby the need to compare the water quality of the River with that of the Estuary. They take dips in the water from the boats which make this investigation even more relevant. Five stations along the River were identified. Stations 1, 2, 3 are in Calabar River while stations 4 and 5 are in the Estuary (figs.1 and 2). Station 1 is directly beside a municipal urban drainage which drains water directly into the River. Station 2 is directly beside a holiday resort (Marina resort). Marina Resort attracts many visitors, among them tourists. Station 3 is directly beside a fish market. The locals often bathe here. There are also farming activities going on around here. Stations 4 and 5 are along the Estuary and are fishing areas.

\section{Methodology}

Sample Collection

Sampling was carried out fortnightly according to Fresenius et al (1988) using a research boat - Plankton Fischer. Water samples were collected, put in an ice box (temperature approx. $4^{0} \mathrm{C}$ ) and taken as soon as possible to the laboratory for analysis.

\section{Isolation of Indicator organisms}

For the isolation of total and fecal coliform, the membrane filter technique was utilized using Endo medium. Approximately $2 \mathrm{ml}$. of Endo medium was added to the pad contained in the dish. The dish was covered until the water sample has been filtered through the membrane. The filter was then placed on a filter holder and clamped in position below the funnel, and the water sample $(100 \mathrm{ml}$.) poured into the funnel and passed through the Millipore filter by the aid of a vacuum pump. The funnel was removed and the filter disk, handled with sterile forceps was then placed on the pad previously impregnated with the endo medium. Total coliform plates were incubated at $35^{\circ} \mathrm{C}$ for 20 hours while fecal coliform plates were incubated at $44^{\circ} \mathrm{C}$ for the same duration at which time the number of coliform colonies were determined. Presumptive, confirmed and completed tests were carried out (Pelczar et al 1977).

KF streptococcus agar was used to isolate intestinal Enterococci. Water sample $(100 \mathrm{ml})$ was passed through the $0.45 \mu \mathrm{m}$ membrane filter which retains the bacteria. The filter was placed on KF streptococcus agar (in triplicates) and incubated at $35^{\circ} \mathrm{C}$ for $48 \mathrm{~h}$. Red and pink colonies were counted. 


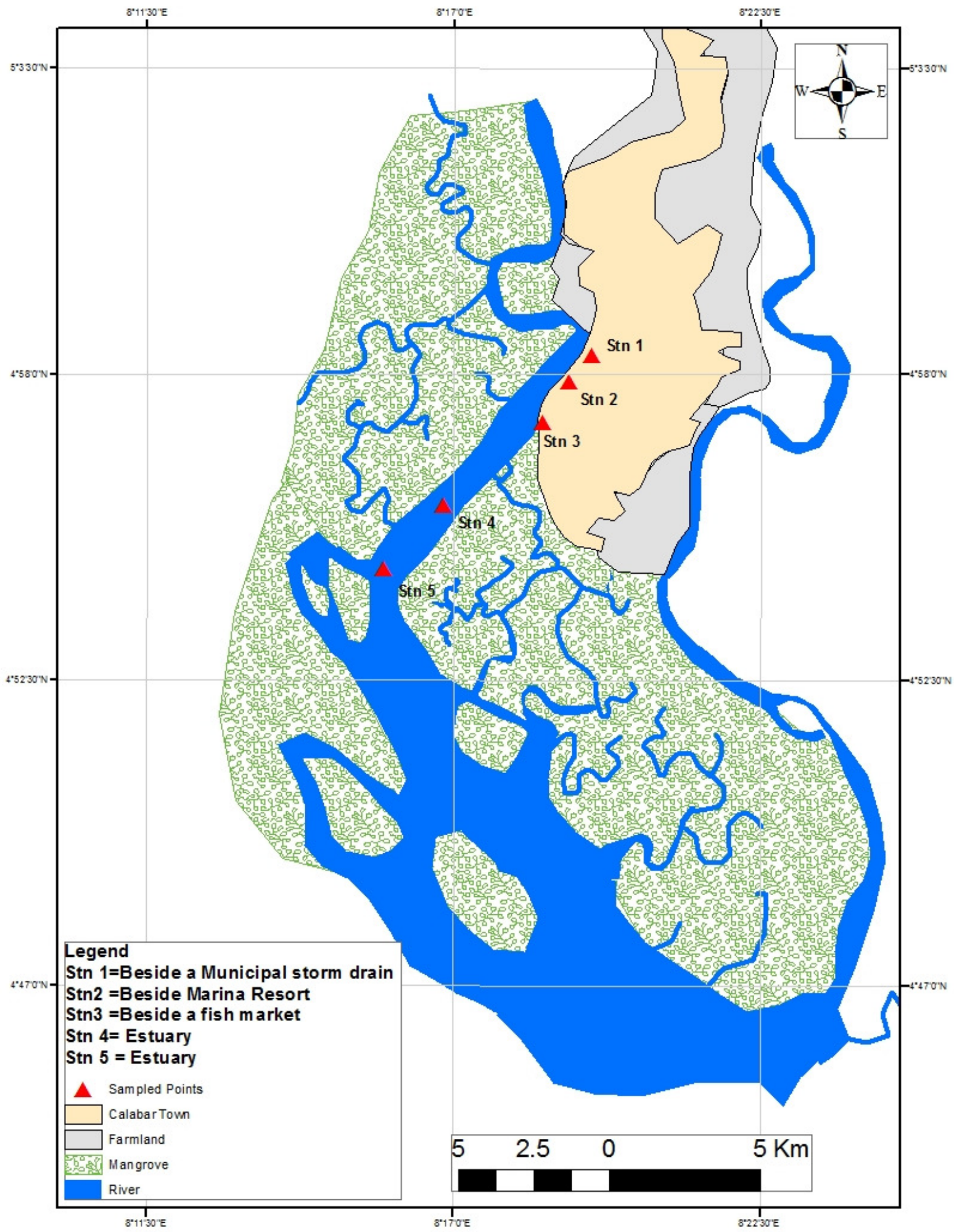

Figure 1: Map of Calabar showing sampled stations 


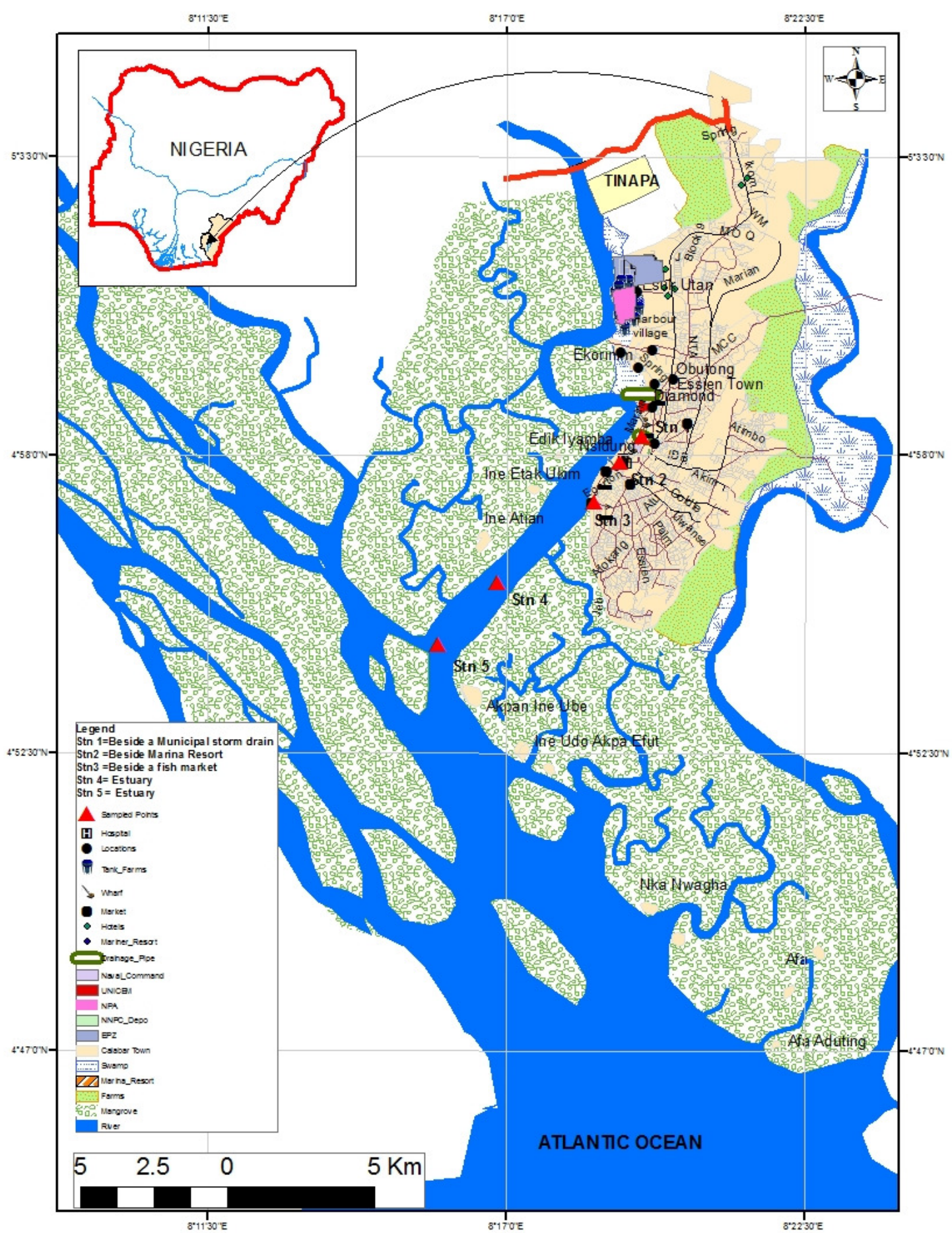

Figure 2: Map of Calabar indicating the immediate anthropogenic environment. 
A Comparison of the Boating and Swimming Microbial Water Quality................SHOWELL et al.

Result

Table 1: Total coliform count in water $(\mathrm{cfu} / 100 \mathrm{ml})$

\begin{tabular}{lllllll}
\hline Month & Tide & St.1 & St.2 & St.3 & St.4 & St.5 \\
\hline Feb.'09 & Ft. & 509 & 475 & 598 & 426 & 404 \\
& Et. & 386 & 327 & 401 & 379 & 413 \\
Mar.'09 & Ft. & 665 & 588 & 679 & 627 & 602 \\
& L. & 594 & 453 & 509 & 491 & 624 \\
Apr.'09 & Ft. & 795 & 679 & 800 & 473 & 408 \\
& Et. & 798 & 550 & 751 & 480 & 301 \\
May'09 & Ft. & 1681 & 1510 & 1601 & 1540 & 1500 \\
& Et. & 1563 & 1524 & 1599 & 1533 & 1490 \\
June'09 & Ft. & 1714 & 1591 & 1813 & 1635 & 1499 \\
& Et. & 1312 & 1246 & 1401 & 1398 & 1579 \\
July'09 & Ft. & 1874 & 1617 & 1900 & 1572 & 1696 \\
& Et & 1790 & 1308 & 1798 & 1695 & 1477 \\
Aug.'09 & F. & 1453 & 1329 & 1521 & 1195 & 1239 \\
& Et. & 1381 & 1193 & 1586 & 902 & 1006 \\
Sept.'09 & Ft. & 1128 & 1083 & 1095 & 983 & 1001 \\
& E. & 1140 & 986 & 1002 & 996 & 998 \\
Oct.'09 & Ft. & 800 & 579 & 648 & 573 & 600 \\
& Et. & 721 & 400 & 480 & 382 & 472 \\
Nov.'09 & Ft. & 460 & 200 & 640 & 600 & 520 \\
& Et. & 378 & 163 & 501 & 471 & 371 \\
Dec.'09 & Ft. & 1660 & 1240 & 1440 & 1020 & 931 \\
& Et. & 1295 & 939 & 1401 & 926 & 560 \\
Jan'2010 & Ft. & 795 & 679 & 800 & 627 & 601 \\
& Et. & 798 & 550 & 751 & 491 & 624 \\
\hline
\end{tabular}

Table 2: Fecal coliform count in water $(\mathrm{cfu} / 100 \mathrm{ml})$

\begin{tabular}{lllllll}
\hline Month & Tide & St.1 & St.2 & St.3 & St.4 & St.5 \\
\hline Feb. '09 & Ft. & 37 & 30 & 41 & 37 & 34 \\
& E. & 32 & 27 & 35 & 35 & 36 \\
Mar. '09 & Ft. & 53 & 45 & 59 & 42 & 47 \\
& Et. & 48 & 40 & 50 & 44 & 41 \\
Apr. '09 & Ft. & 67 & 58 & 61 & 55 & 52 \\
& E. & 69 & 54 & 59 & 51 & 53 \\
May '09 & Ft. & 190 & 178 & 187 & 170 & 176 \\
& Et. & 183 & 180 & 181 & 164 & 160 \\
June '09 & Ft. & 198 & 193 & 201 & 188 & 189 \\
& Et. & 190 & 194 & 197 & 183 & 191 \\
July '09 & Ft. & 205 & 183 & 250 & 194 & 95 \\
& Et. & 187 & 184 & 189 & 173 & 82 \\
Aug. '09 & F. & 181 & 179 & 194 & 165 & 176 \\
& Et. & 174 & 171 & 178 & 167 & 168 \\
Sept. '09 & Ft. & 158 & 142 & 152 & 136 & 147 \\
& E. & 149 & 137 & 154 & 130 & 144 \\
Oct. '09 & Ft. & 130 & 141 & 126 & 118 & 124 \\
& Et. & 121 & 127 & 129 & 120 & 122 \\
Nov. '09 & Ft. & 98 & 83 & 119 & 89 & 87 \\
& Et. & 91 & 76 & 129 & 72 & 77 \\
Dec. '09 & Ft. & 200 & 172 & 182 & 164 & 147 \\
& Et. & 191 & 174 & 176 & 158 & 140 \\
Jan. '09 & Ft. & 127 & 119 & 153 & 110 & 110 \\
& Et. & 113 & 106 & 138 & 112 & 112 \\
\hline
\end{tabular}


Table 3: Intestinal Enterococci count in water (cfu/ml)

\begin{tabular}{|c|c|c|c|c|c|c|}
\hline Month & Tide & St.1 & St.2 & St.3 & St.4 & St.5 \\
\hline \multirow[t]{2}{*}{ Feb. '09 } & & 52 & 49 & 59 & 44 & 42 \\
\hline & Et. & 39 & 34 & 39 & 39 & 43 \\
\hline \multirow{2}{*}{ Mar. '09 } & Ft. & 68 & 60 & 69 & 60 & 60 \\
\hline & Et. & 58 & 46 & 52 & 47 & 62 \\
\hline \multirow[t]{2}{*}{ Apr. '09 } & Ft. & 78 & 66 & 81 & 49 & 44 \\
\hline & Et. & 77 & 54 & 77 & 50 & 31 \\
\hline \multirow[t]{2}{*}{ May '09 } & Ft. & 169 & 152 & 158 & 152 & 148 \\
\hline & Et. & 157 & 153 & 155 & 151 & 147 \\
\hline \multirow[t]{2}{*}{ June '09 } & Ft. & 172 & 160 & 180 & 165 & 153 \\
\hline & Et. & 132 & 126 & 139 & 141 & 155 \\
\hline \multirow[t]{2}{*}{ July '09 } & Ft. & 188 & 163 & 191 & 159 & 171 \\
\hline & Et. & 181 & 132 & 180 & 171 & \\
\hline \multirow{2}{*}{ Aug. '09 } & Ft. & & & & & $\begin{array}{l}149 \\
121\end{array}$ \\
\hline & Et. & $\begin{array}{l}14 / \\
140\end{array}$ & $\begin{array}{l}131 \\
118\end{array}$ & $\begin{array}{l}154 \\
160\end{array}$ & 01 & $\begin{array}{l}121 \\
123\end{array}$ \\
\hline \multirow[t]{2}{*}{ Sept. '09 } & Ft. & 114 & 108 & 111 & 98 & 101 \\
\hline & Et. & 115 & 97 & 102 & 101 & 103 \\
\hline \multirow[t]{2}{*}{ Oct. '09 } & Ft. & 80 & 59 & 66 & 59 & 63 \\
\hline & Et. & 73 & 39 & 49 & 39 & 49 \\
\hline \multirow[t]{2}{*}{ Nov. '09 } & Ft. & 47 & 21 & 63 & 60 & 52 \\
\hline & Et. & 39 & 17 & 48 & 48 & 54 \\
\hline \multirow[t]{2}{*}{ Dec. '09 } & $\mathrm{Ft}$ & 167 & 125 & 144 & 102 & 95 \\
\hline & Et. & 131 & 95 & 139 & 90 & 59 \\
\hline \multirow[t]{2}{*}{ Jan. 10} & Ft. & 78 & 66 & 82 & 64 & 58 \\
\hline & Et. & 79 & 54 & 76 & 51 & 53 \\
\hline
\end{tabular}

Table 4: $95^{\text {th }}$ Percentile of intestinal Enterococci count

\begin{tabular}{lllllll}
\hline Month & Tide & St.1 & St.2 & St.3 & St.4 & St.5 \\
\hline Feb.'09 & Ft. & 50 & 45 & 58 & 42 & 41 \\
& Et. & 36 & 32 & 35 & 36 & 41 \\
Mar.' 09 & Ft. & 65 & 57 & 68 & 56 & 59 \\
& Et. & 57 & 42 & 50 & 42 & 62 \\
Apr. '09 & Ft. & 77 & 66 & 75 & 47 & 37 \\
& Et. & 73 & 65 & 74 & 48 & 27 \\
May '09 & Ft. & 162 & 151 & 154 & 148 & 143 \\
& Et. & 156 & 152 & 150 & 149 & 144 \\
June '09 & Ft. & 166 & 159 & 176 & 158 & 151 \\
& Et. & 127 & 125 & 136 & 135 & 147 \\
July '09 & Ft. & 186 & 160 & 190 & 154 & 170 \\
& Et. & 177 & 131 & 172 & 159 & 147 \\
Aug. '09 & Ft. & 196 & 128 & 152 & 112 & 119 \\
& Lt. & 139 & 117 & 155 & 89 & 122 \\
Sept. '09 & Ft. & 107 & 100 & 107 & 96 & 96 \\
& Lt. & 114 & 95 & 100 & 97 & 102 \\
Oct. '09 & Ft. & 79 & 49 & 58 & 58 & 56 \\
& Et. & 71 & 34 & 44 & 36 & 46 \\
Nov. '09 & Ft. & 46 & 14 & 61 & 56 & 51 \\
& Et. & 38 & 14 & 47 & 46 & 49 \\
Dec. '09 & Ft. & 166 & 123 & 143 & 101 & 89 \\
& Et. & 125 & 90 & 132 & 89 & 50 \\
Jan. '10 & Ft. & 70 & 65 & 80 & 55 & 53 \\
& Et. & 72 & 50 & 75 & 49 & 52 \\
\hline
\end{tabular}


Table 5: Variation in microbial water quality between the near-shore and estuary waters of Calabar River Estuary

\begin{tabular}{llll}
\hline Parameter & T & df & Sig. \\
\hline Total Coliform count & 1.458 & 46 & 0.152 \\
Fecal Coliform count & 1.258 & 46 & 0.215 \\
Intestinal Enterococci & 1.359 & 46 & 0.181 \\
\hline
\end{tabular}

\section{Discussion}

Total coliform count in Calabar River ranged from 163-1900cfu/100ml while count in the Estuary ranged from 301$1696 \mathrm{cfu} / 100 \mathrm{ml}$ (table 1). Fecal coliform count in Calabar River ranged from 27$250 \mathrm{cfu} / 100 \mathrm{ml}$ while count in the Estuary ranged from 34-194cfu/100ml (table 2). The highest total coliform count was recorded in station 3 which is in Calabar River during the wet season at flood tide (figure 3). For fecal coliform the highest count was also recorded in station 3 in Calabar River during the wet season at flood tide (figure 5). Omoigberale et al (2013) investigated seasonal variation in the bacteriological quality of Ebutte River in Edo state, Southern Nigeria and reported that bacterial counts were highest in the wet season and the least total viable count were recorded in the dry season month of January. Human activities in this station as hitherto described may also have played a significant role in the higher number of both total and fecal coliforms at station 3 . Edun and Efiuvwevwere (2012) in their work on bacterial profiles and physicochemical parameters of water samples from different sites in the new Calabar River, Nigeria reported that the different sites had different bacterial and physico- chemical parameters profile and attributed this to the anthropogenic and industrial activities of the sites.

The lowest counts for both total and fecal coliform were recorded in station 2 (figures 2 and 4). This could be attributed to the fact that the station is directly beside Marina resort which is very well kept with no negative human activities such as using the environment there as a toilet as in station 3. Although the lowest counts of both total and fecal coliform were recorded in Calabar River, Stations 4 and 5 in the estuary had relatively lower total and fecal coliform counts (tables 1 and 2). The highest total and fecal coliform count for these estuarine stations were $1696 \mathrm{cfu} / \mathrm{ml}$ (table 1) and $194 \mathrm{cfu} / \mathrm{ml}$ (table 2) respectively while the highest in Calabar River were $1900 \mathrm{cfu} / \mathrm{ml}$ and $250 \mathrm{cfu} / \mathrm{ml}$ respectively for total coliform and fecal coliform.

According to extracts from the WHO (2003) and EC (2002) guidelines, the number of total coliform in bathing waters should not be more than 10,000 cfu (Colony forming units) in $100 \mathrm{ml}$ of the water. Also, the number of fecal coliform in $100 \mathrm{ml}$ of the water should not be more than 2,000cfu in this study, all the stations satisfied the above stated standards. 


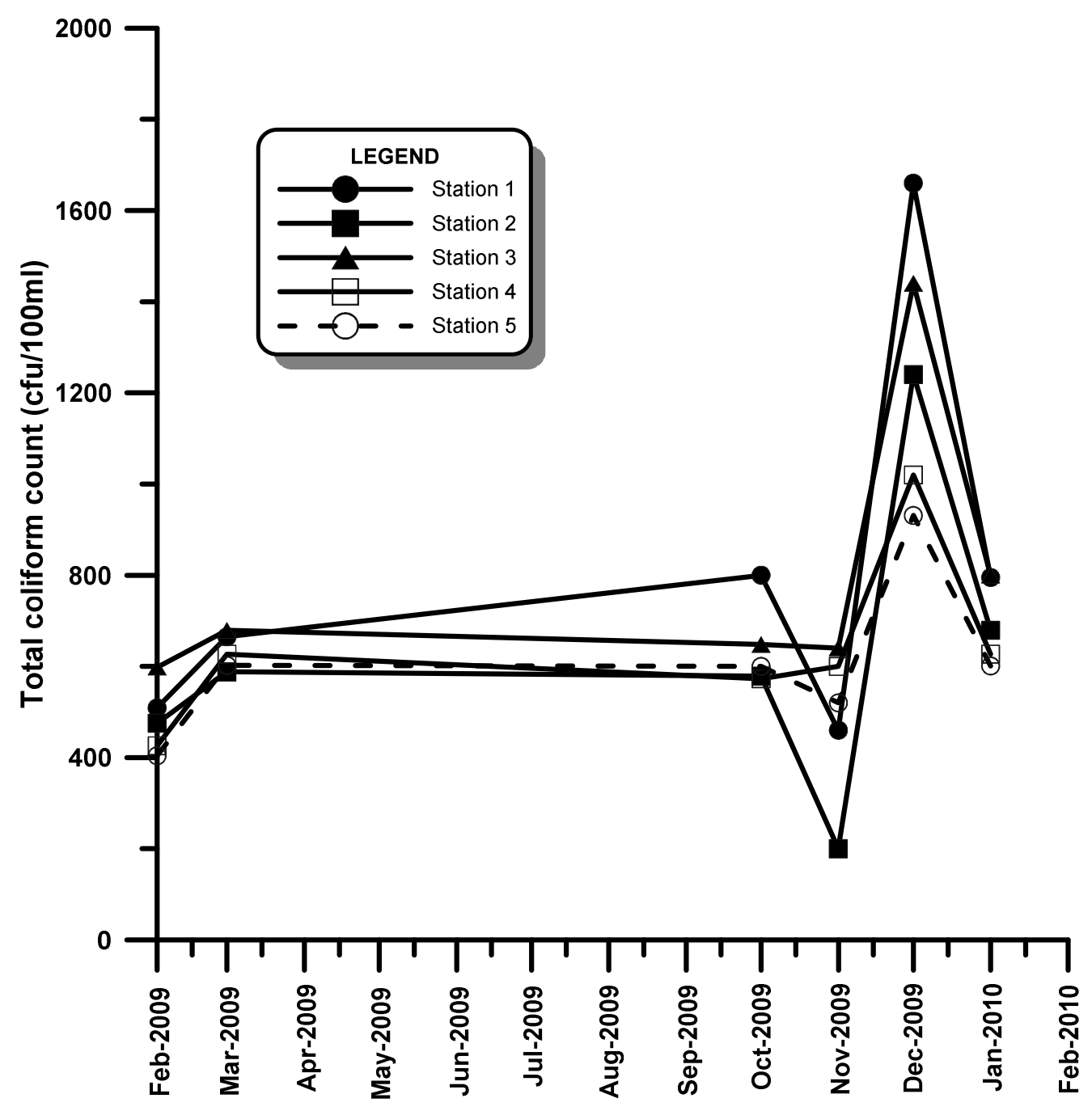

Figure 2: Plot of total coliform during dry season months at ebb tide 
A Comparison of the Boating and Swimming Microbial Water Quality................SHOWELL et al.

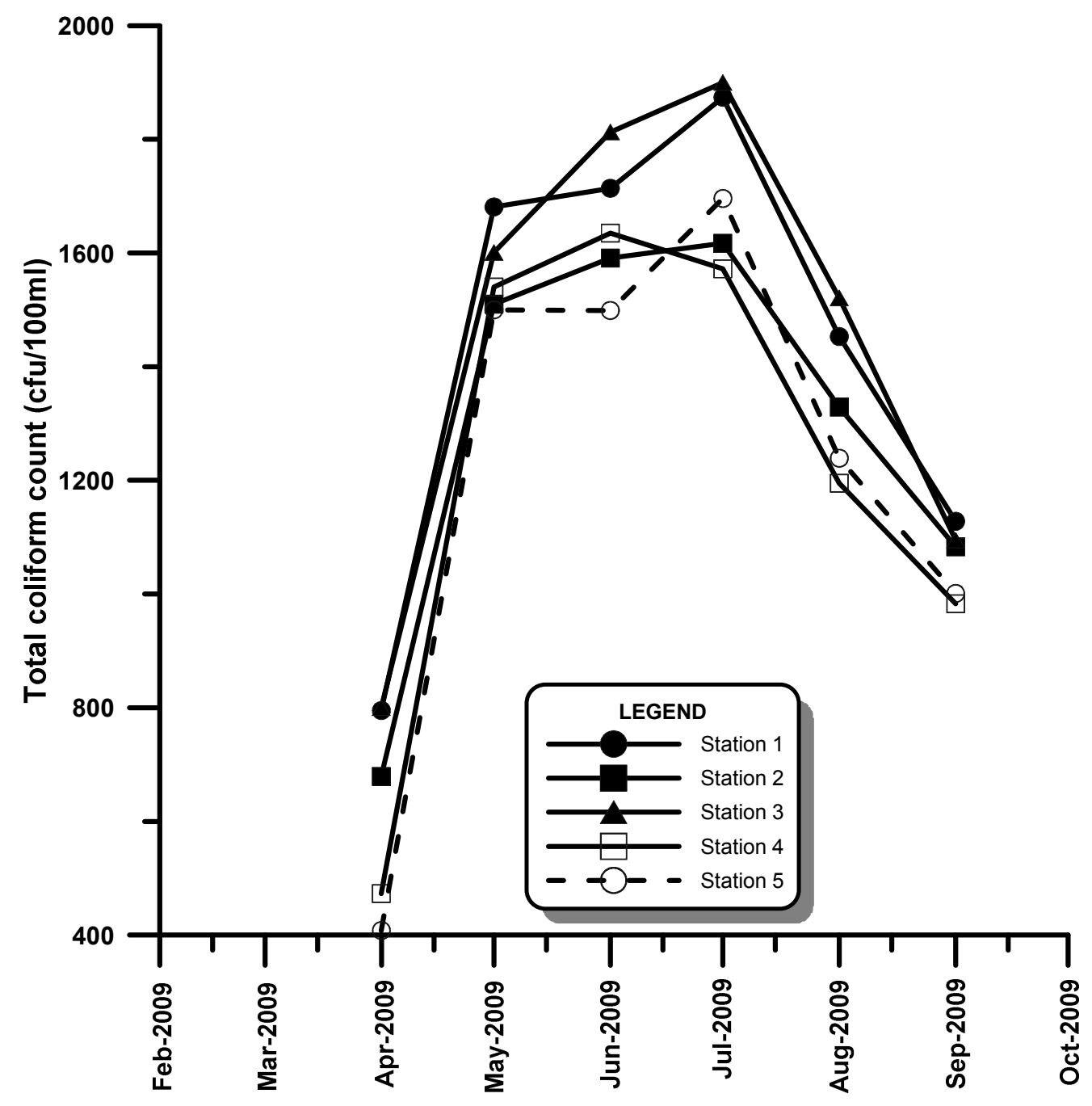

Figure 3: Plot of total coliform count during wet season months at flood tide 


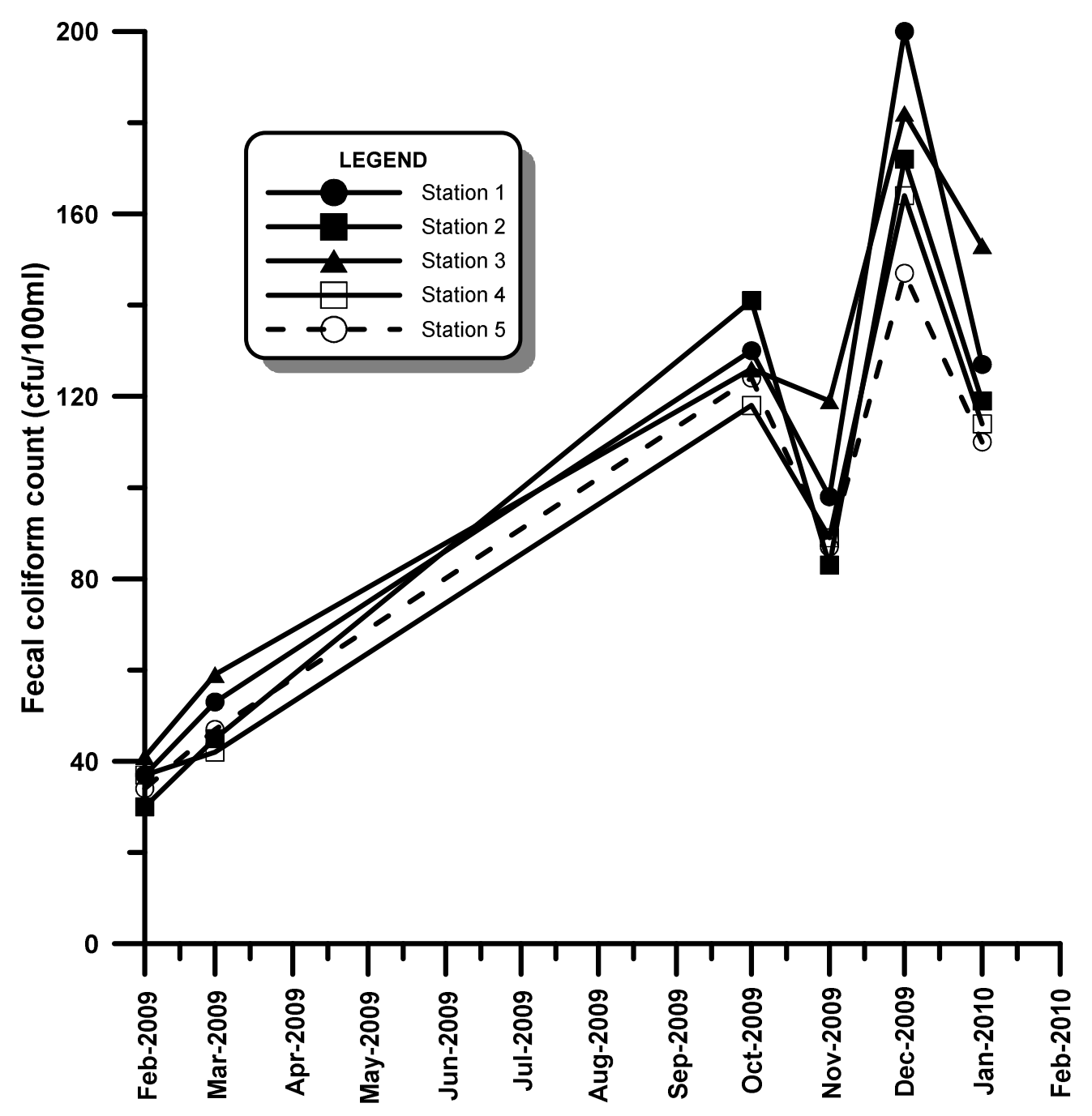

Figure 4: Plot of fecal coliform count during the dry season at ebb tide 


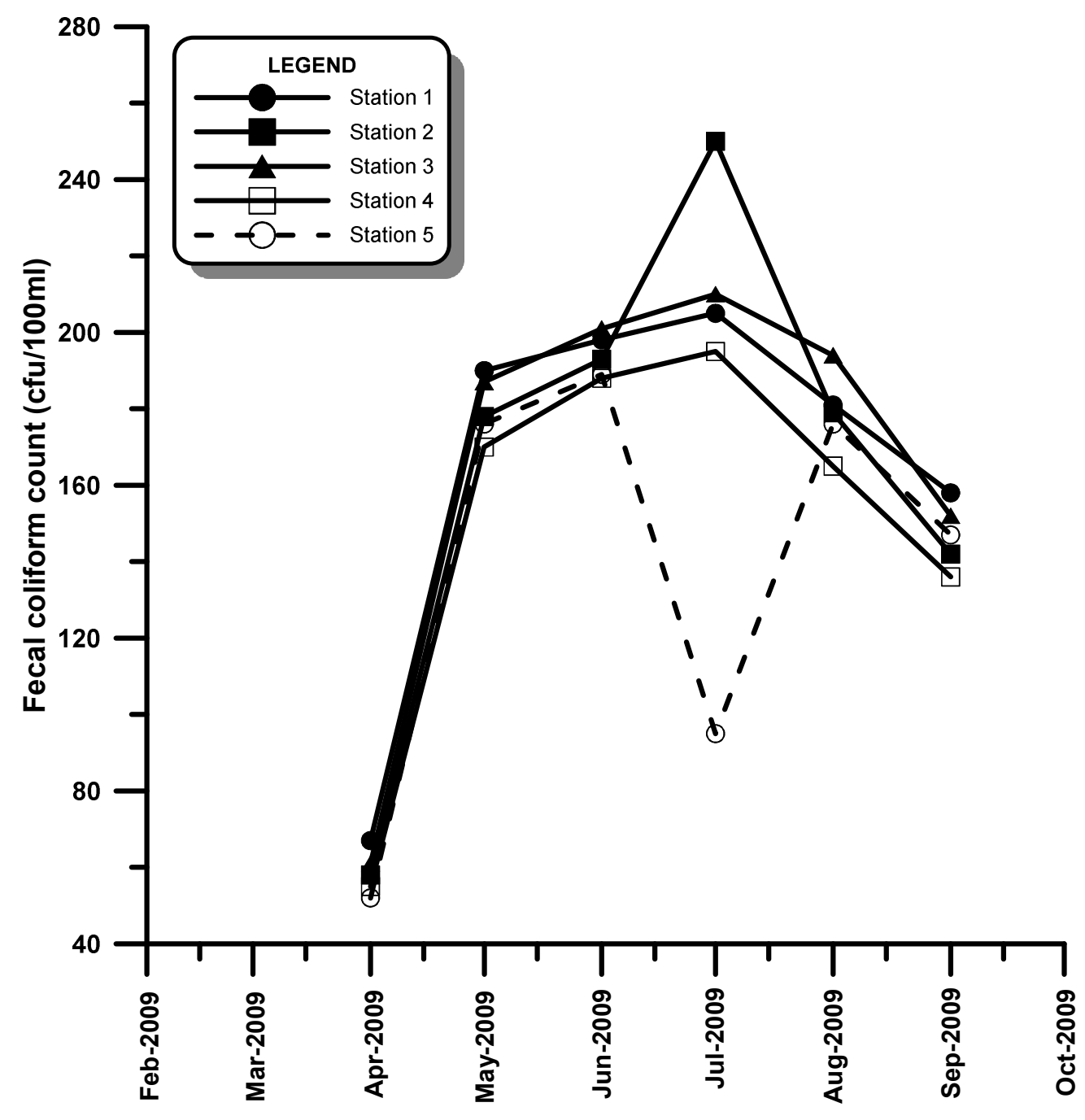

Figure 5: Plot of fecal coliform count during wet season months at flood tide. 


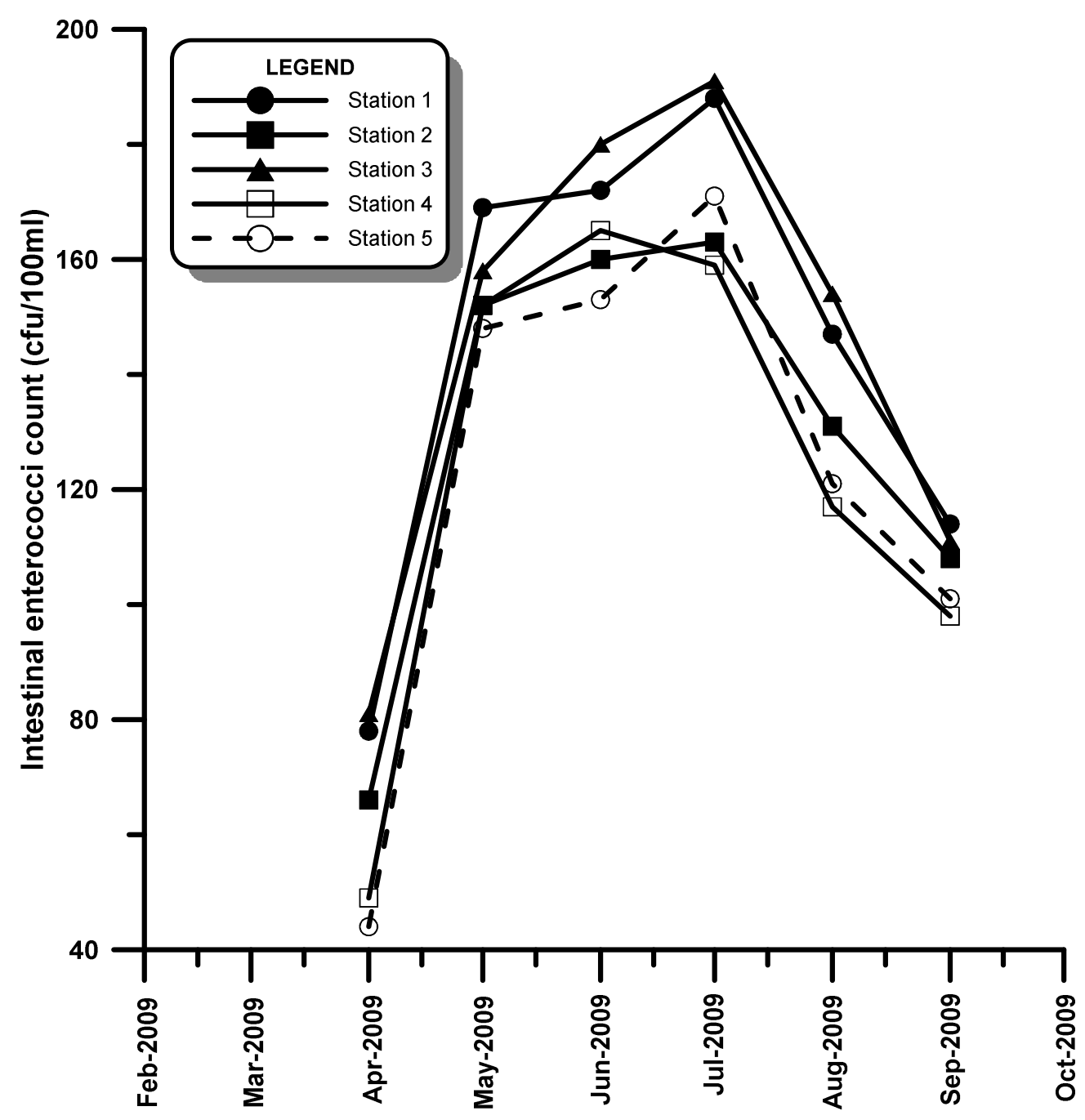

Figure 6: Plot of intestinal Enterococci count during the wet season months at flood tide 


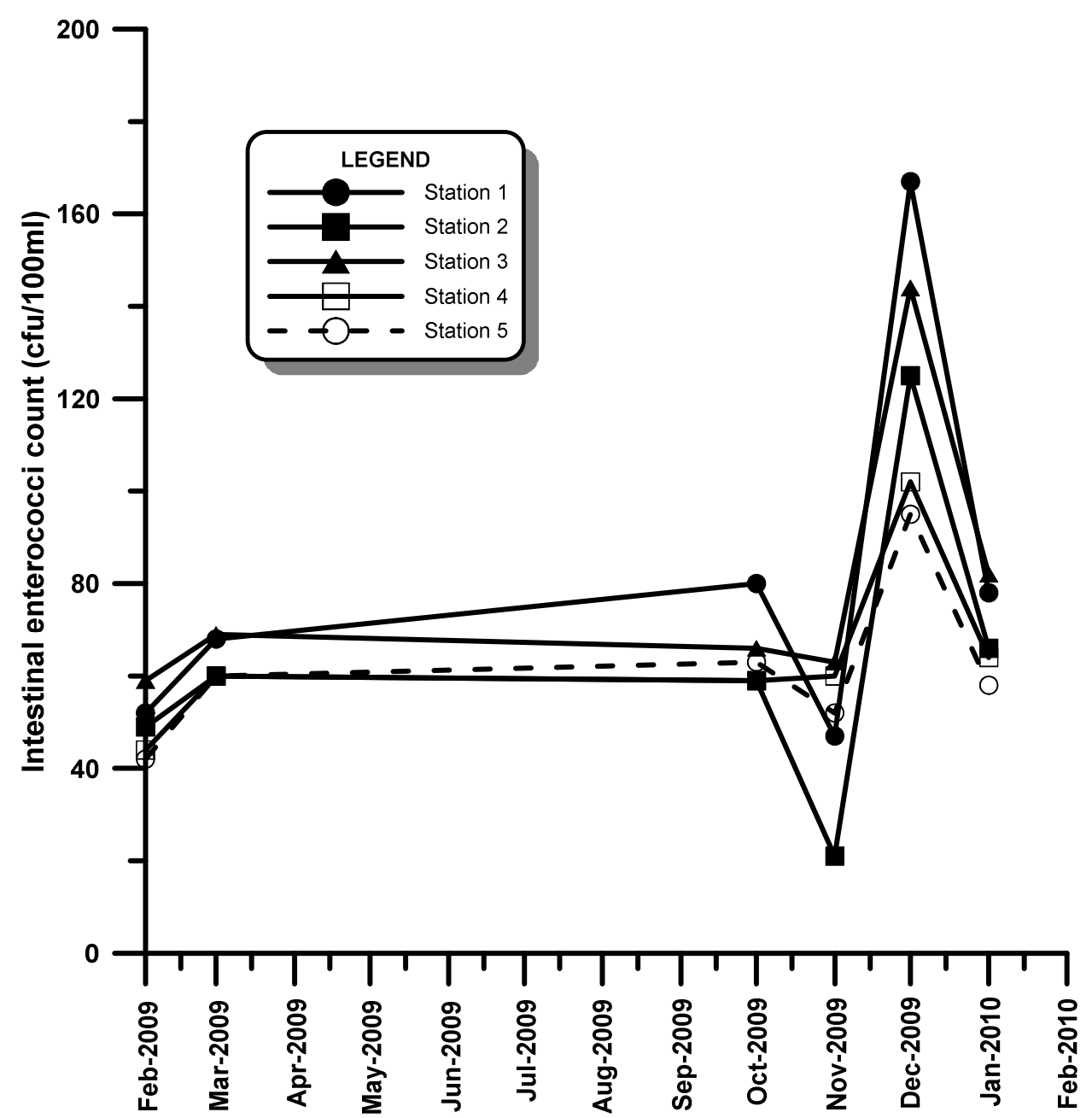

Figure 7: Plot of intestinal Enterococci count during dry season months at ebb tide

For intestinal Enterococci, the count in Calabar River ranged from 17 - 191cfu/ml while the count in the Estuary ranged from $31-171 \mathrm{cfu} / \mathrm{ml}$ (table 3 ). Stations $1-3$ were in Calabar River while stations 4-5 were in the Estuary. Although the highest count was recorded in Calabar River, a sampling station here (station 2) just like in the case of total and fecal coliform also recorded the lowest count of intestinal Enterococci during this study $(17 \mathrm{cfu} / 100 \mathrm{ml})$. The $95^{\text {th }}$ percentile value of intestinal Enterococci at this station was $14 / 100 \mathrm{ml}$ (table 4). As already mentioned, station 2 is directly beside Marina resort. The resort attracts visitors who sometimes take boat rides in the water. This is good news as it indicated that this was the safest point among the sampled stations for recreational activity in the water and is where tourists are often seen taking dips in the water while on boat rides.

The highest count of intestinal Enterococci $(191 / 100 \mathrm{ml})$ was recorded at station 3 also during the wet season at flood tide (figure 6) while the lowest was recorded at station 2 in November (figure $7)$. The $95^{\text {th }}$ percentile was $190 / 100 \mathrm{ml}$ (table 4). As already mentioned, station 3 has a lot of human activities going on. The 
station is beside a fish market. Moreover, many locals defecate into the water here and are often seen bathing in the River water here. There are also farming activities going on in the area surrounding this sampling station. Organic and inorganic fertilizers are freely used. This beach area is also where fishermen take off and land as they undertake their fishing activities. The local people are frequently cooking, washing cooking utensils and plates here. All these human activities may have contributed to the high intestinal Enterococci load at this sampling station. Station 4 and 5 which are in the Estuary had the lowest count of intestinal Enterococci. For example, the lowest count throughout the sampling period was recorded in station 5 (table 5). This could be attributed to the far distance between these stations and the land from where human activities impact microbial water quality. Mallin et al. (2000) had reported that the most important anthropogenic factor associated with bacterial abundance was percentage watershed - impervious surface coverage which consists of roofs, roads, driveways, sidewalks and parking lots. These surfaces serve to concentrate and convey storm water-borne pollutants to downstream receiving waters which explain why the inshore stations had more bacterial load than the estuarine ones. Their work again demonstrates the influence of human activities on the microbial profile of a water body.

The World Health Organization guidelines for safe recreational waters (WHO, 2003) recommend $95^{\text {th }}$ percentile value of intestinal Enterococci per 100ml of water sample of $40-500$ depending on the category of the water. WHO (2003) has four categories, A-D: In category A water, the $95^{\text {th }}$ percentile value should not be more than $40 / 100 \mathrm{ml}$. of water. This value relates to an average probability of less than one case of gastroenteritis in every 100 exposures. The acute febrile respiratory illness (AFRI) burden would be negligible. In category B water, the $95^{\text {th }}$ percentile value of Enterococci should be $41-200 / 100 \mathrm{ml}$ of water. This value relates to an average probability of one case of gastroenteritis in 20 exposures. The AFRI illness rate at this upper value would be less than 19 per 1000 exposures, or less than approximately 1 in 50 exposures. Category $\mathrm{C}$ water is bathing water that has $95^{\text {th }}$ percentile of $201-500 / 100 \mathrm{ml}$. The value represents a probability of 1 in 10 to 1 in 20 gastroenteritis for a single exposure. Exposures in this category also suggest a risk of AFRI in the range of 1939 per 1000 exposures, or a range of approximately 1 in 50 t0 1 in 25 exposures. Category D bathing water has more than $500 / 100 \mathrm{ml}$. In this range, there is a greater than $10 \%$ chance of gastroenteritis per single exposure. The AFRI illness rate at this range would be greater than 39 per 1000 exposures, or greater than approximately 1 in 25 exposures. Above this level, there could be a major risk of high incidences of minor illness transmission (UNEP, 2001)

\section{Conclusion}

In this study, none of the sampled stations had $95^{\text {th }}$ percentile of intestinal Enterococci of more than 200/100ml of the water which means sampled stations were in categories $\mathrm{A}$ and $\mathrm{B}$ and met the WHO standard (WHO,2003) for safe recreational waters as far as intestinal Enterococci count was concerned. As expected, it was observed that standards were better during the dry season (table 6). These standards are however for healthy adults and may not relate to children, the elderly or the immunocompromised, who could have 
lower immunity and might require a degree of protection

As indicated in table 7 the t-value of total coliform count was 1.458 at 46 degrees of freedom and 0.152 significant level. The tvalue of fecal coliform count was 1.258 at 46 degrees of freedom and 0.215 significant value. By the same token, the tvalue of intestinal Enterococci count was 1.359 , at 46 degrees of freedom and 0.181 significant level. The table shows that none of the significant levels is less than or equal to 0.05 which concludes that there was no significant difference in microbial water quality between Calabar River and the estuary.

\section{References}

Adelegen, J.A. (2004). The history of environmental policy and pollution of water resources in Nigeria (19602004): the way forward. http://userpage.fu-

berlin.de/ffu/akumwelt/be2004/downlo ad/adelegen-f.pdf

Akoachere, J.T.K., Oben, P.M., Mbivnjo, B.S., Ndip, L.L.M., Nkwelong, G. and Ndip, R.N. (2008). Bacterial indicators of pollution of the Doula lagoon, Cameroon: Public Health implications. African Health Science. 8(2): 85-89.

Arnold, C.L. and Gibbons, C.J. (1996). Inpervious surface coverage: The emergence of a key environmental indicator. Amer. Planning Assn. J., 62: 243-258.

Asuquo, F.E. (1999). Physicochemical characteristics and anthropogenic pollution of the surface waters of Calabar River, Nigeria. Global Journal of Pure and Applied Sciences, 5(4): 595-600.

Bannerman, R.T., Owens, D.W., Dudds, R.B. and Hornewer, N.J. (1993). Sources of pollutants in Wisconson storm water. Water Sci. Tech., 28: 241259.

City of Sao Paulo (1998). Secretaris de Estado Meio Ambiente Balneabilidade das praisas paulistas.

CRBDA (1982). Inventory of natural site conditions, soils, slopes, hydrology, land use and vegetation throughout the area of operation of the authority. Progress report no. 4, 145p.

EC (2002). EC Bathing Water Directive 76/160/EEC and its proposed revision. http://www.europa.eu.int/water/waterbathing/index en. html.

Edun, O.M. and Efiuvwevwere, B.J.O. (2012). Bacterial profiles and physicochemical parameters of water samples from different sites of New Calabar River, Nigeria. Sustainable Agricultural Research. Vol. 1, no. 2.

Eze, B.E. and Effiong, J. (2010). Morphometric parameters of the Calabar River Basin: Implications for hydrologic processes. Journal of Geography \& Geology, 2(1): 18-26.

Mallin, M.A., Williams, K.E., Esham, E.C. and Lowe, R.P. (2000). Effect of human development on bacteriological water quality in coastal watersheds. Ecological Applications, 10(4): 1047 1056.

Omoigberaele, M.N.O., Isibor, J.O., Izegaegbe, J.I. and Iyamu, U.I. (2013). Seasonal variation in the bacteriological quality of Ebutte River in Ehor community , Edo State, Nigeria. Amer. Journ. of Res. Comm. 1(7): 59-69.

Pelczar, M. J., Roger, D.R. and Chan, E.C.S. (1977). Microbiology. Fourth Edition. McGraw - Hill Inc.

UNEP (2001). Protecting the Oceans from land-based activities. Rep. Stud. GESAMP No. 71, 162pp.

WHO (2003). Guidelines for safe recreational water environments. Vol. 1. Coastal and Fresh Waters. 70-71. 